DOI: 10.15342/ATD.V1IR.293

\title{
PERSPECTIVE
}

\section{Towards the 9th Edition of the Tumour, Node and Metastasis Classification of Lung Cancer. A Historical Appraisal and Future Perspectives*}

\section{VERS LA 9ÉME ÉDITION DE LA CLASSIFICATION DE LA TUMEUR, DES GANGLIONS ET DES MÉTASTASES DU CANCER DU POUMON. UNE ÉVALUATION HISTORIQUE ET PERSPECTIVES FUTURES*}

\author{
Ramón RAMI-PORTA (D), MD, PhD, FETCS 1, 2, 3
}

\begin{abstract}
1: Department of Thoracic Surgery, Hospital Universitari Mútua Terrassa, University of Barcelona, Terrassa, Barcelona, Spain.
2: Network of Centres for Biomedical Research in Respiratory Diseases (CIBERES) Lung Cancer Group, Terrassa, Barcelona, Spain.

3: Past-Chair, International Association for the Study of Lung Cancer Staging and Prognostic Factors Committee.

* This article is liberally based on a lecture presented by the author at the European Lung Cancer Conference, Geneva, Switzerland, 10th-13th April 2019.
\end{abstract}

\begin{abstract}
Since 1966 the classification of anatomic extent of lung cancer, based on the primary tumour $(\mathrm{T})$, the loco-regional lymph nodes $(\mathrm{N})$ and the metastases $(\mathrm{M})$ has been used in the management of lung cancer patients. Developed by Pierre Denoix, it was adopted by the Union for International Cancer Control and the American Joint Committee on Cancer. Clifton Mountain revised the second through the sixth editions based on a North American database of more than 5000 patients. For the seventh and the eighth editions, the International Association for the Study of Lung Cancer (IASLC) collected international databases of around 100,000 patients worldwide that allowed the introduction of innovations in both editions, namely the subdivision of the $\mathrm{T}$ and $\mathrm{M}$ categories based on tumour size and on the location and number of metastases, respectively. The revisions also showed the prognostic relevance of the quantification of nodal disease, and proposed recommendations on how to measure tumour size for solid lung cancers, part-solid adenocarcinomas, and for lung cancers removed after induction therapy. Despite the innovations, prognosis based on the anatomic extent is limited, because prognosis depends on factors related to the tumour, the patient and the environment. For the 9th edition, these factors, especially genetic biomarkers, will be combined in prognostic groups to refine prognosis at clinical and pathologic staging. To achieve this challenging objective, international cooperation is essential, and the IASLC Staging and Prognostic Factors Committee counts on it for the development of the 9th edition due to be published in 2024.
\end{abstract}

KEY WORDS: Lung cancer - TNM classification - staging - 9th edition TNM.

RESUME : Depuis 1966, la classification anatomique basée sur la tumeur primitive (T), les adénopathies loco-régionales $(\mathrm{N})$ et les métastases $(\mathrm{M})$, est utilisée pour la stadification et la prise en charge des patients avec un cancer du poumon. Développée par Pierre Denoix, elle a été adoptée par l' Union for International Cancer Control et l'American Joint Committee on Cancer. Clifton Mountain avait révisé de la seconde à la sixième éditions utilisant une base de données nord américaine de plus de 5000 patients. Pour la septième et la huitième éditions, l’International Association for the Study of Lung Cancer (IASLC) avait rassemblé deux 
bases de donnés d'environ 100.000 patients à travers le monde. Ceci avait permis d'y introduire des nouvelles notions à savoir la subdivision des catégories $\mathrm{T}$ et $\mathrm{M}$ sur la base de la taille de la tumeur, le site et le nombre des métastases. Les révisions avaient également mis en évidence le rôle pronostique de la quantification de la maladie ganglionnaire, et avaient proposé des recommandations pour mesurer la taille des tumeurs solides, la part-solide des adénocarcinomes et les tumeurs réséquées après un traitement d'induction. Malgré ces innovations, le pronostic basé sur l'anatomie seule est limité, parce qu'il dépend d'autres facteurs liés à la tumeur, au malade et à l'environnement. Pour la neuvième édition, ces facteurs, spécialement les biomarqueurs génétiques, seront combinés pour créer des groupes pronostiques qui affineront la stadification clinique et pathologique. Pour atteindre cet objectif difficile, l'IASLC et Prognostic Factors Committee comptent sur la coopération internationale pour développer la neuvième édition qui sera publiée en 2024.

MOTS-CLES : Cancer du poumon - classification TNM - stadification - 9émé édition TNM.

Corresponding author: Ramón Rami-Porta, Department of Thoracic Surgery, Hospital Univesitari Mútua Terrassa, Plaza Dr. Robert 5, 08221 Terrassa, Barcelona, Spain. Tel: +34-937365050; Fax: +34-937365059; email: rramip@yahoo.es

\section{Copyright $@ 2019$ Ramón Rami-Porta}

This is an open access article distributed under the Creative Commons Attribution 4.0 International, which permits unrestricted use, distribution, and reproduction in any medium, provided the original work is properly cited.

\section{INTRODUCTION}

The 8th edition of the tumour, node and metastasis (TNM) classification of lung cancer, published in 2016, is being used all over the world and will not be replaced by the 9th edition until 2024 [1-3]. However, the expectation is so great that specialists of all domains involved in the management of lung cancer patients want to know what can be expected from the 9th edition, the database of which still is being collected at the time of this writing [4]. In order to fully understand where we are and where we are going to regarding the TNM classification of lung cancer, it is important to have in mind some historical highlights that have made the periodical revision of the classification possible, adding some advances with every edition. The purpose of this article is to revise important historical facts and developments that led to the 7th and 8th editions of the TNM classification of lung cancer, and to venture into the innovations of the forthcoming 9th edition.

\section{HISTORICAL HIGHLIGHTS OF THE TNM CLASSIFICATION OF LUNG CANCER}

In the mid 20th century, Pierre Denoix (1912-1990), a surgical oncologist from the Hospital Gustave Rousy, Paris, France, wrote a series of articles on the anatomic extent of malignant tumours based on three components: the primary tumour (T), the loco-regional lymph nodes $(\mathrm{N})$ and the metastases (M). It took almost a decade to the Union for International Cancer Control (UICC) to adopt this classification. Initially, the UICC published fascicles with the classification of individual tumours, the one for lung cancer appearing in 1966. In 1968, the UICC published the first edition of its TNM Classification of Malignant Tumours in the format we know today. The American Joint Committee on Cancer (AJCC) adopted the
TNM classification and published its first staging manual in 1977. Until the 5th edition, the UICC and the AJCC published their own editions independently, but since 1997 they have been published simultaneously and the classifications have been conceptually the same [5].

In the 1970's, Clifton Mountain (1924-2007), a thoracic surgeon from the MD Anderson Cancer Center, Houston, Texas, USA, collected a series of patients from North America who had been diagnosed of lung cancer. They had been treated mainly by resection, but the tumours had been classified clinically and pathologically. This database, that in its final years of use had more than 5,000 patients, informed five successive editions of the TNM classification of lung cancer, from the 2nd to the 6th, published from 1975 to 2002 [5].

No doubt, Mountain's database gave the TNM classification of lung cancer solid grounds from where it could be revised, but the data were not truly international and did not represent all forms of lung cancer therapy. In 1996, acknowledging these limitations, Peter Goldstraw, a thoracic surgeon for the Royal Brompton Hospital, London, UK, proposed the creation of an international database to revise subsequent editions of the TNM classification. The Board of Directors of the International Association for the Study of Lung Cancer (IASLC) approved the idea, and the first IASLC Staging Committee was constituted in 1998 with the objective to develop the IASLC Lung Cancer Staging Project, a data-based revision process of the TNM classification of lung cancer [5]. For the revisions leading to the 7th and 8th editions, the IASLC databases included 81,495 (68,463 with non-small cell lung cancer and 13,032 with small cell lung cancer) and 77,156 (70,967 with non-small cell lung cancer and 6,189 with small cell lung cancer) evaluable patients, 
respectively [6, 7]. The proposals for changes suggested by the IASLC were accepted by the UICC and the AJCC, were incorporated into the 7th and 8th editions, and subsequently published in the UICC and the AJCC staging manuals. The IASLC databases built with the specific purpose of revising the TNM classification of lung cancer gave the revision process even more solid grounds and a degree of internationality never achieved before. With this data-based revision process, the IASLC became the most important provider of evidences for the UICC and the AJCC. These institutions had based their revisions on results from published reports, usually single institution experiences, or on the suggestions of the National TNM Committees in various parts of the world.

Reference 5 is a complete report on the history of the TNM classification of lung cancer. It can be downloaded for free from: www.iaslc.org $\rightarrow$ Research \& Education $\rightarrow$ Staging $\rightarrow$ IASLC 8th Edition Staging Educational Materials.

\section{A NOTE ON THE FIRST EDITION TNM FOR LUNG CANCER}

It all started with the first edition of the UICC, shown in Table 1.

Table 1. First edition of the TNM classification of lung cancer

\begin{tabular}{ll}
\hline Categories & Descriptors \\
\hline T0 & No evidence of primary tumour \\
T1 & Tumour confined to segment/segmental bronchus \\
T2 & Tumour confined to lobe/lobar bronchus \\
T3 & Tumour involves main bronchus or more than one lobe \\
T4 & Tumour extends beyond the lung \\
NX & Nodal involvement cannot be assessed \\
N0 & No nodal involvement \\
N1 & Enlargement of intrathoracic lymph nodes \\
M0 & No evidence of distant metastases \\
M1a & Pleural effusion with malignant cells \\
M1b & Palpable cervical nodes \\
M1c & Other distant metastases \\
\hline
\end{tabular}

The descriptors defining the different $\mathrm{T}$ categories were rather simple by today's standards. The most important tumour characteristic was its location in relation with the lung parenchyma or bronchi, and its extension beyond the lung. The enlargement of the intrathoracic lymph nodes, with no more specification, qualified for N1 disease, the N2 category not having been described, yet. Then, the M component included a variety of different conditions, such as malignant pleural effusion, palpable nodes, but only in the cervical region, and other distant metastases. Interestingly, the three M1 categories are exactly the same the 8th edition has, although their descriptors are very different [5]. They were modified in subsequent editions, malignant pleural effusion being transferred to the $\mathrm{T}$ category as it was thought at that time that all disease encompassed within the chest should be defined by a $\mathrm{T}$ category. However, malignant pleural effusion has poor prognosis, more in line with metastatic disease and its treatment is mainly palliative like most cases of metastatic disease. So, in later editions, malignant pleural effusion was moved to the $\mathrm{M}$ component, which is were it is now in the 8th edition TNM, coded as M1a like other intrathoracic metastases.

\section{PROGRESS IN THE 7TH AND 8TH EDITIONS}

The increasing relevance of tumour size

In the first six editions of the TNM classification of lung cancer, tumour size played a limited role as a descriptor. The 3-cm landmark separated T1 from T2 tumours with no other role. In the database analyses leading to the changes in the 7th edition, tumour size proved to be a more important descriptor than it had been thought of in previous editions. The analyses on the prognostic impact of tumour size allowed the subclassification of $\mathrm{T} 1$ and $\mathrm{T} 2$ into T1a and T1b, and T2a and T2b, respectively. There also was enough evidence to transfer tumours more than $7 \mathrm{~cm}$ in greatest dimension from $\mathrm{T} 2$ to T3 [8].

The relevance of tumour size as a $\mathrm{T}$ descriptor able to separate tumours of significantly different prognosis was even more evident in the analyses of the database of the 8th edition. The T1 category was further subdivided into $\mathrm{T} 1 \mathrm{a}, \mathrm{T} 1 \mathrm{~b}$ and $\mathrm{T} 1 \mathrm{c}$, at $1 \mathrm{~cm}$ intervals from $\leq 1 \mathrm{~cm}$ to $3 \mathrm{~cm}$ in greatest dimension. The $\mathrm{T} 2$ category kept its subdivisions, but the T2a and T2b subcategories were redefined to code tumours of $>3-\leq 4 \mathrm{~cm}$, and $>4-\leq 5 \mathrm{~cm}$ in greatest dimension, respectively. Tumours of $>5-\leq 7 \mathrm{~cm}$ were assigned to the T3 category; and tumours $>7 \mathrm{~cm}$ were included in the T4 category (Table 2). For the first time in the history of the TNM classification of lung cancer, tumour size is a descriptor of all T categories. In addition to the changes based on tumour size, in the 8th edition TNM endobronchial location less than $2 \mathrm{~cm}$ from the carina and atelectasis or pneumonitis involving the whole lung were transferred to the T2 category, because their prognosis was found to be more similar to the prognosis of the other $\mathrm{T} 2$ descriptors than to that of the T3 descriptors. The invasion of the diaphragm was reclassified as T4 and invasion of the mediastinal pleura was deleted as a $\mathrm{T}$ descriptor because very few tumours are classified exclusively with this descriptor [9].

Table 2. Evolution of tumour size as a $\mathrm{T}$ descriptor in the latest three editions of the TNM classification of lung cancer.

\begin{tabular}{|c|c|c|c|}
\hline Tumour size & & T categories & \\
\hline & $6^{\text {th }}$ edition & $7^{\text {th }}$ edition & $8^{\text {th }}$ edition \\
\hline No size & T0 & T0 & T0 \\
\hline $\begin{array}{l}\text { Size cannot be } \\
\text { assessed }\end{array}$ & $\mathrm{TX}$ & $\mathrm{TX}$ & $\mathrm{TX}$ \\
\hline $\begin{array}{l}\text { Squamous cell } \\
\text { carcinoma im situ }\end{array}$ & Tis & Tis & Tis (SCIS) \\
\hline $\begin{array}{l}\text { Adenocarcinoma in } \\
\text { situ }\end{array}$ & $\mathrm{N} / \mathrm{A}$ & N/A & Tis (AIS) \\
\hline $\begin{array}{l}\text { Minimally invasive } \\
\text { adenocarcinoma }\end{array}$ & N/A & $\mathrm{N} / \mathrm{A}$ & Tlmi \\
\hline$\leq 1 \mathrm{~cm}$ & T1 & T1a & T1a \\
\hline$>1 \mathrm{~cm} \cdot \leq 2 \mathrm{~cm}$ & $\mathrm{~T} 1$ & Tla & Tlb \\
\hline$>2 \mathrm{~cm} \cdot \leq 3 \mathrm{~cm}$ & $\mathrm{~T} 1$ & Tlb & Tlc \\
\hline$>3 \mathrm{~cm}-\leq 4 \mathrm{~cm}$ & $\mathrm{~T} 2$ & T2a & T2a \\
\hline$>4 \mathrm{~cm} \cdot \leq 5 \mathrm{~cm}$ & $\mathrm{~T} 2$ & T2a & $\mathrm{T} 2 \mathrm{~b}$ \\
\hline$>5 \mathrm{~cm} \cdot \leq 7 \mathrm{~cm}$ & $\mathrm{~T} 2$ & $\mathrm{~T} 2 \mathrm{~b}$ & $\mathrm{~T} 3$ \\
\hline$>7 \mathrm{~cm}$ & $\mathrm{~T} 2$ & T3 & $\mathrm{T} 4$ \\
\hline
\end{tabular}

N/A: not available.

\section{Newcomers into the staging system}

Between the publication of the 7th and the 8th editions, the new classification of adenocarcinomas of the lung was published [10] and subsequently accepted by the World Health Organization, who included it in the 2015 WHO book on pathology of the lung, pleura, thymus and heart [11]. Two new tumours were defined: adenocarcinoma in 
situ and minimally invasive adenocarcinoma. These two entities needed to be incorporated into the TNM system and were coded as Tis(AIS) and T1mi, respectively. The addition of (AIS) after Tis was necessary to differentiate adenocarcinoma in situ from squamous cell carcinoma in situ, Tis(SCIS), that already existed in the TNM classification [12]. Table 3 shows the distinctive features of these two tumours $[10,11]$.

Table 3. Distinctive features of adenocarcinoma in situ and minimally invasive adenocarcinoma.

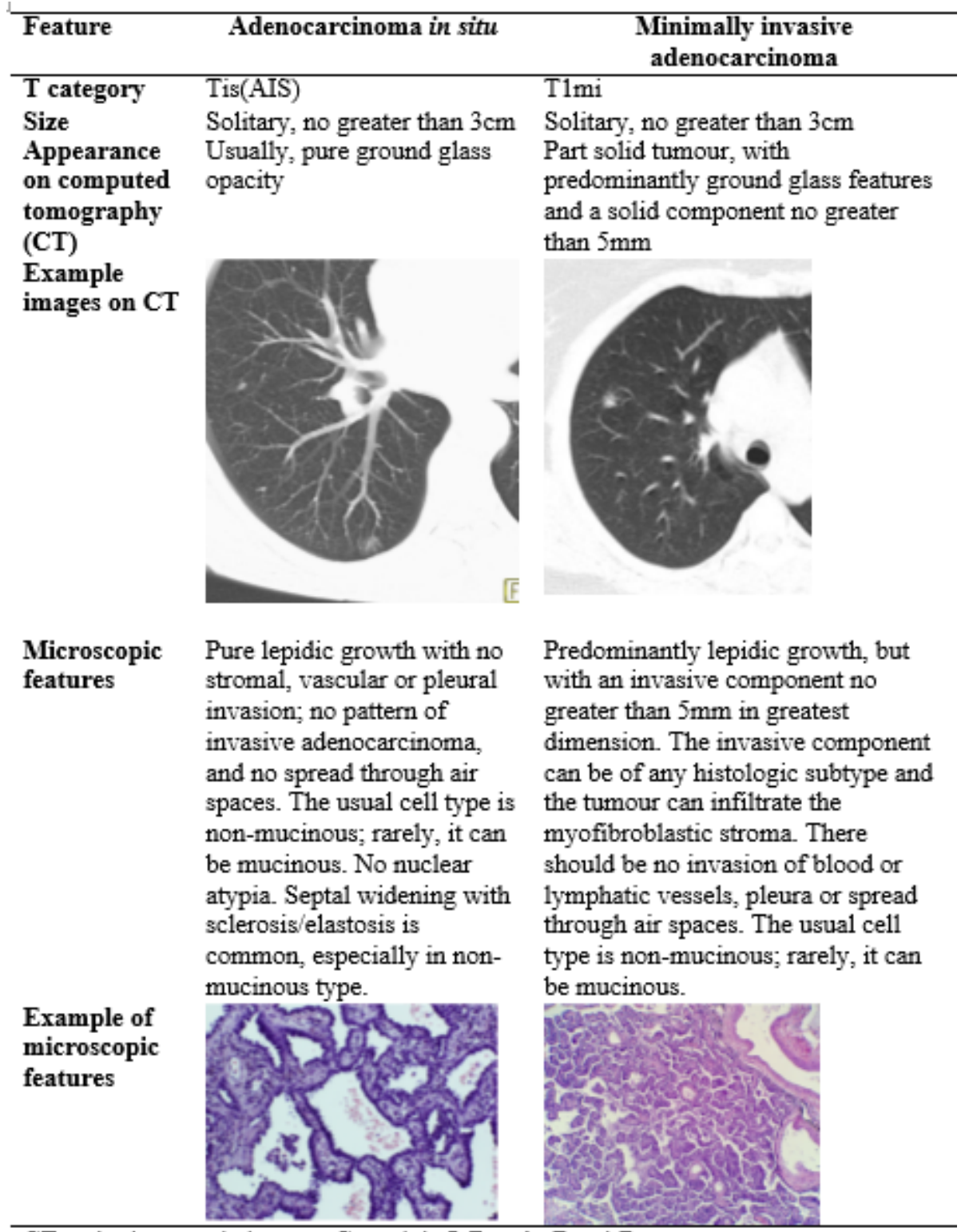

CT and microscopic images, Copyright Ramón Rami-Porta.

In the 8th edition TNM, there are a group of very small tumours the presence of which will be more relevant because they all have distinct categories: Tis(AIS), Tis(SCIS), T1mi and T1a. It is a group that will prompt research in different ways: from the study of various forms of therapy (potential indication of sublobar resections, the need of systematic nodal dissection, the use of alternative treatments, such as stereotactic radiotherapy, radiofrequency or microwave ablation) to the study of their biology (growth, density, positron emission tomography uptake, molecular profile, genetic signatures, etc.).
Specific rules for the measurement of tumour size

There are more categories based on tumour size and, therefore, this will require a more precise measurement of the greatest dimension of the tumour. In previous editions, the only requirement was to register the greatest dimension of the tumour, but the rules of the classification did not say how to measure it. In the 8th edition, the IASLC has recommended to measure tumour size on CT on the lung window, in order not to underestimate tumour size, and to use not only the axial projection, but also the coronal and the sagittal, if available, because it may happen that the greatest dimension of the tumour is not the one given by the axial projection. 
There are rules for special cases. For part solid nonmucinous adenocarcinoma, the rule is to use the size of the solid component on CT for clinical staging, and the size of the invasive component at pathologic staging to assign a $\mathrm{T}$ category based on size, although the registration of both the total tumour size and the size of the solid/invasive component is recommended. Mucinous adenocarcinomas follow the general rules. Finally, in the 8th edition TNM there is a new recommendation: the measurement of tumour size after induction therapy. In these cases, there might be scattered tumour cells difficult to measure. The recommendation is to multiply the percentage of viable cells by the size of the residual mass [12]. For example: in a resected tumour measuring $3.5 \mathrm{~cm}$ in which the pathologist has found $20 \%$ of viable cells, the tumour size to assign a $\mathrm{T}$ category based on size would be: $20 \% \mathrm{x}$ $3.5 \mathrm{~cm}=0.7 \mathrm{~cm}$. The pathological $(\mathrm{p}) \mathrm{T}$ category after induction (y) treatment would be ypT1a.

\section{Progress in understanding the invasion of the visceral pleura}

Visceral pleura invasion was defined in the 7th edition as the invasion of its elastic layer, and was divided into two categories: PL1, tumour invasion beyond the elastic layer without reaching the surface of the lung; and PL2, tumour invasion of the lung surface. At that time, it was recommended to use elastic stains if the elastic layer was not clearly seen on hematoxylin \& eosin stains [13]. The same definition and recommendation are kept in the 8th edition, but more insight was gained from the analyses of the new database: PL1 and PL2 had significantly different prognosis, that of PL2 being worse than that of PL1 [8]. This feature can rarely be determined at clinical staging, and, therefore, it cannot be used to modify the present $\mathrm{T}$ categories. However, it has prognostic relevance postoperatively in those patients whose tumours have been removed and show pathologic signs of visceral pleura invasion. The use of elastic stains has to be emphasized and strongly recommended. In a series of 100 lung cancers pathologically classified as stage I, the use of elastic stains revealed invasion of the pleural invasion in 19 of them [14]. Figure 1 shows how the use of elastic stains can facilitate the diagnosis of visceral pleura invasion.

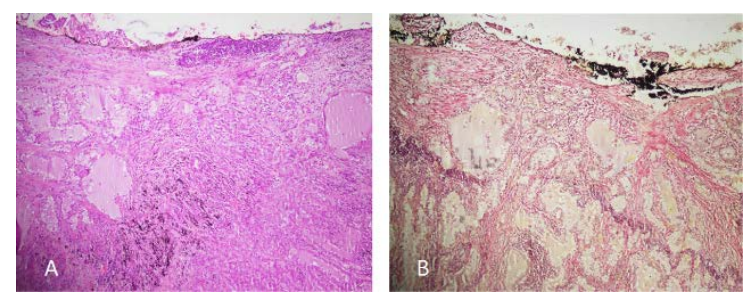

Figure 1. A: Hematoxylin and eosin, PL2 100X. B: Elastic stains, PL2 $\underline{100 X}$. The figures show invasion of the visceral pleura reaching the lung surface (PL2). In figure B, the elastic layer is clearly highlighted by the elastic stains; the elastic layer is disrupted and the tumour invades beyond

it reaching the lung surface. (Courtesy of Dr. Francisco Pérez Ochoa, Department of Pathology, Hospital Universitari Mútua Terrassa, Terrassa, Barcelona, Spain).

\section{Classification of lung cancers with multiple lesions}

Classifying lung cancers with multiple lesions according to the rules of previous editions of the TNM classification was a difficult task. The wording was rather vague and sometimes the rules differed slightly in the UICC and in the AJCC texts. All this led to various interpretations and to a lack of homogeneity when classifying these tumours. To try to solve this problem, an ad hoc committee was created within the IASLC Staging and Prognostic Factors Committee to study in depth this problem and to find a solution. The Multiple Pulmonary Sites of Cancer Workgroup, lead by Dr. Frank Detterbeck, consisted of a team of multidisciplinary and international specialist interested in the topic. To approach this complex problem, they broke it down into four disease patterns: 1) second primary lung cancers; 2) separate tumour nodules; 3) multifocal adenocarcinomas with ground glass/lepidic features; and 4) pneumonic type adenocarcinoma.

The work of this group resulted in the publication of four articles describing the background of each disease pattern and providing recommendations for clinical and pathologic staging. One of the articles is a summary of the other three for quick reference [15]. The other three deal with second primaries [16], separate tumour nodules [17], and multifocal adenocarcinomas and pneumonic type adenocarcinoma [18]. Table 4 shows the recommended TNM classification for each pattern of disease, along with the basic imaging and pathologic features and the conceptual view of each type of tumour [15].

\section{Bronchopulmonary carcinoids join the TNM}

Before the 7th edition TNM, bronchopulmonary carcinoids were excluded from the classification. For the 7th edition, 513 patients from the IASLC database and 1619 from the Surveillance, Epidemiology and End Results (SEER) database diagnosed between 1990 and 2000, and 1990 and 2002, respectively, were analysed. The results showed that the $\mathrm{T}$, the $\mathrm{N}$ and the $\mathrm{M}$ categories defined for non-small cell lung cancer were useful to classify and stage bronchopulmonary carcinoids, despite the fact that most patients had been surgically treated and differentiating between typical and atypical carcinoids was not possible. Therefore, the inclusion of bronchopulmonary carcinoids in the TNM classification of lung cancer was recommended [19]. This recommendation was accepted by the UICC and the AJCC and duly specified in their staging manuals.

\section{Small cell lung cancer: better TNM than limited/extended disease}

Exploratory analyses regarding the application of the TNM system to small cell lung cancer were done for the 7th and the 8th editions. From the results of the analyses it was clear that the TNM classification also works well for small cell lung cancer, separating tumours with differing anatomic extent and statistically significant different prognosis [20, 21, 22]. The survival curves of clinically and pathologically staged tumours are much worse than those of non-small cell lung cancer, reflecting the different 
natural history and biologic behaviour of this tumour, but they show progressive worsening as the $\mathrm{T}$, the $\mathrm{N}$ and the $\mathrm{M}$ categories, and the stages increase. The use of the TNM classification for small cell lung cancer is favoured over the classic dichotomous limited versus extensive disease, because, although treatment may not change as a result of the application of the TNM classification, prognosis can be refined if it is applied. The distinct prognosis provided by the TNM stages I, II and III is diluted in the allencompassing limited disease of the dichotomous classification.

Another clinically relevant fact that the analyses revealed was the disagreement between clinical and pathologic staging. In the 7th edition, the percentage of agreement between the clinical and pathologic $\mathrm{T}$ categories was $74 \%$, best for T4 (91\%) and worse for T3 (44\%). For the N categories, the concordance was $69 \%$, best for N1 (75\%) and worse for N2 (66\%) [21]. The respective percentages of agreement in the 8th edition were $71 \%$ for the $\mathrm{T}$ categories, best for T2a (85\%) and worse, again, or T3 (50\%). The agreement for the $\mathrm{N}$ categories was $73 \%$, best for N0 (79\%) and worse for N1 (52\%), if we exclude the $25 \%$ agreement for N3 because there were 4 patients, only. The agreement for N2 disease was 55\% [22]. These percentages of agreement indicate that clinical staging should be more thorough and that, at least in those patients deemed candidates for tumour resection, invasive mediastinal staging should be performed.

Table 4. Summary of patterns of disease and TNM classification of lung cancers

\begin{tabular}{|c|c|c|c|c|}
\hline Features & $\begin{array}{l}\text { Second Primary } \\
\text { Lung Cancer }\end{array}$ & $\begin{array}{c}\text { Separate } \\
\text { Tumor Nodule } \\
\text { (Intrapulmonary } \\
\text { Metastasis) }\end{array}$ & $\begin{array}{c}\text { Multifocal } \\
\text { GG/L Nodules }\end{array}$ & $\begin{array}{l}\text { Pneumonic-Type } \\
\text { of Adenocarcinoma }\end{array}$ \\
\hline $\begin{array}{l}\text { Imaging } \\
\text { features }\end{array}$ & $\begin{array}{l}\text { Two or more } \\
\text { distinct masses } \\
\text { with imaging } \\
\text { characteristics of } \\
\text { lung cancer (e.g. } \\
\text { spiculated) }\end{array}$ & $\begin{array}{l}\text { Typical lung } \\
\text { cancer (e.g. solid, } \\
\text { spiculated) with } \\
\text { separate solid } \\
\text { nodule }\end{array}$ & $\begin{array}{l}\text { Multiple ground } \\
\text { glass or part-solid } \\
\text { nodules }\end{array}$ & $\begin{array}{l}\text { Patchy areas of } \\
\text { ground glass and } \\
\text { consolidation }\end{array}$ \\
\hline $\begin{array}{l}\text { Pathologic } \\
\text { features }\end{array}$ & $\begin{array}{l}\text { Different histotype } \\
\text { or different } \\
\text { morphology by } \\
\text { comprehensive } \\
\text { histologic } \\
\text { assessment }\end{array}$ & $\begin{array}{l}\text { Distinct masses } \\
\text { with the same } \\
\text { morphologic } \\
\text { features by } \\
\text { comprehensive } \\
\text { histologic } \\
\text { assessment }\end{array}$ & $\begin{array}{l}\text { Adenocarcinomas } \\
\text { with prominent } \\
\text { lepidic component } \\
\text { (typically varying } \\
\text { degrees of AIS, } \\
\text { MIA, LPA) }\end{array}$ & $\begin{array}{l}\text { Same histologic } \\
\text { features throughout } \\
\text { (most often invasive } \\
\text { mucinous } \\
\text { adenocarcinoma) }\end{array}$ \\
\hline $\begin{array}{l}\text { TNM } \\
\text { classi- } \\
\text { fication }\end{array}$ & $\begin{array}{l}\text { Separate cTNM } \\
\text { and pTNM for } \\
\text { each cancer }\end{array}$ & $\begin{array}{l}\text { Location of } \\
\text { separate nodule } \\
\text { relative to primary } \\
\text { site determines if } \\
\text { T3 (same lobe), T4 } \\
\text { (different lobe, } \\
\text { ipsilateral lung) or } \\
\text { M1a (contralateral } \\
\text { lung); single N and } \\
\text { M }\end{array}$ & $\begin{array}{l}\mathrm{T} \text { based on highest } \\
\mathrm{T} \text { lesion with }(\# / \mathrm{m}) \\
\text { indicating } \\
\text { multiplicity; single } \\
\mathrm{N} \text { and } \mathrm{M}\end{array}$ & $\begin{array}{l}\mathrm{T} \text { based on size or } \\
\mathrm{T} 3 \text { if in single lobe, } \\
\mathrm{T} 4 \text { or M1a if in } \\
\text { different ipsilateral } \\
\text { or contralateral } \\
\text { lobes; single N and } \\
\mathrm{M}\end{array}$ \\
\hline $\begin{array}{l}\text { Conceptual } \\
\text { view }\end{array}$ & Unrelated tumours & $\begin{array}{l}\text { Single tumour, } \\
\text { with } \\
\text { intrapulmonary } \\
\text { metastasis }\end{array}$ & $\begin{array}{l}\text { Separate tumours, } \\
\text { albeit with } \\
\text { similarities }\end{array}$ & $\begin{array}{l}\text { Single tumour, } \\
\text { diffuse pulmonary } \\
\text { involvement }\end{array}$ \\
\hline
\end{tabular}

\section{Confirmation of the prognostic impact of the amount of nodal disease}

The $\mathrm{N}$ categories of gastrointestinal tumours are based on the number of involved lymph nodes. This is not the case of lung cancer, the $\mathrm{N}$ categories of which are based on the anatomic location of the involved lymph nodes. Many studies have shown that there are other ways to quantify nodal disease in lung cancer: the number of involved nodal stations or nodal zones, and the lymph node ratio, that is the number of involved lymph nodes divided by the number of resected lymph nodes [23]. All these different ways to quantify nodal disease have prognostic relevance: the more nodal disease, the worse the prognosis. The most important limitation of these types of quantification is that they derive from resected specimens and pathologic staging, and can hardly be validated at clinical staging.
For the 7th edition, quantification of nodal disease was done by analysing the number of the newly defined lymph node zones. The lymph node zones are groups of neighbouring lymph node stations and are meant to facilitate nodal staging especially in those patients who do not undergo cancer resection. The survival analyses based on the number of involved lymph node zones showed that involvement of a single N1 zone had better prognosis than the involvement of multiple $\mathrm{N} 1$ zones; however, the involvement of single N2 zone had similar prognosis to that of multiple N1 zone involvement. Finally, the involvement of multiple N2 zones had the worst prognosis [24].

For the 8th edition, a similar analysis was done but considering the number of involved nodal stations, based on the IASLC lymph node map [25]. Again, it was proved 
that the amount of nodal disease had prognostic implications: the involvement of a single N1 station had better survival than the involvement of multiple N1 stations; but the involvement of a single N2 station without $\mathrm{N} 1$ disease had the same prognosis as the involvement of multiple N1 stations; the involvement of a single N2 station with $\mathrm{N} 1$ disease had worse prognosis than the involvement of a single N2 station without N1; and, finally, the involvement of multiple N2 stations had the worst prognosis. Table 5 shows the survival rates of the different types of nodal involvement [26].

Table 5. Survival and comparisons among the different types of nodal involvement at pathologic staging.

\begin{tabular}{lllll}
\hline $\begin{array}{l}\text { Proposed } \\
\text { category }\end{array}$ & Descriptor & \multicolumn{1}{c}{$\begin{array}{c}\text { 5-year } \\
\text { survival rate }\end{array}$} & Hazard ratio* & P value* \\
\hline N1a & $\begin{array}{l}\text { Single N1 } \\
\text { station }\end{array}$ & $58 \%$ & & \\
N1b & $\begin{array}{l}\text { Multiple N1 } \\
\text { stations }\end{array}$ & $50 \%$ & 1.30 & 0.0005 \\
N2a1 & $\begin{array}{l}\text { Single N2 } \\
\text { station without }\end{array}$ & $52 \%$ & 0.92 & 0.4331 \\
N2a2 & $\begin{array}{l}\text { N1 } \\
\text { Single N2 } \\
\text { station with N1 }\end{array}$ & $41 \%$ & 1.37 & 0.0002 \\
N2b & $\begin{array}{l}\text { Multiple N2 } \\
\text { stations }\end{array}$ & $36 \%$ & 1.21 & 0.0117 \\
\hline "Comparing & & &
\end{tabular}

Comparison of N2a2 vs N1b: hazard ratio 1.26, p = 0.0197 .

The proposed categories to subclassify the present ones could not be introduced into the official classification because they lacked clinical and geographic validation: survival curves analysed at clinical staging were anarchic; and most patients used for the analyses of the $\mathrm{N}$ component were from Asia, especially from Japan [26]. They could not be used exclusively as new pathologic categories, either, because, in principle, clinical and pathologic categories should be the same, although there are two tumours with different clinical and pathologic $\mathrm{N}$ categories: breast and penis. In any case, even if these $\mathrm{N}$ categories are not in the official TNM classification, they are useful to refine prognosis and, perhaps, to intensify therapy or follow-up in those patients whose tumours have been resected and have been found to have nodal involvement. They also indicate that, although the present $\mathrm{N}$ categories (NX, N0, N1, N2 and N3) work well separating tumours of significantly different prognosis at clinical and pathologic staging, there are subgroups within the N1 and N2 categories that have different prognosis based on the amount of nodal involvement.

\section{The relevance of location and number of metastases}

Separating intrathoracic from extrathoracic metastases was an innovation of the 7th edition TNM. Intrathoracic metastases, defined as contralateral tumour nodules and malignant pleural or pericardial effusion or nodules, had significantly better prognosis than extrathoracic metastases. Therefore, the traditional M1 category was subdivided into M1a, for intrathoracic metastases, that is, those encompassed within the pleural space, and M1b, for extrathoracic metastases [27]. The analyses that led to the revisions for the 8th edition found that all M1a descriptors had similar prognosis and, therefore, were well assigned to their M1a category. However, when analysing extrathoracic metastases according to their number, one or several, it was found that a single extrathoracic metastasis had significantly better prognosis than several extrathoracic metastases, regardless of being in one or in several organs. Therefore, the 7th edition M1b was redefined to include single extrathoracic metastasis, only, and a new category, M1c, was created for multiple extrathoracic metastases either in one or in several organs. It was also found that a single extrathoracic metastasis had similar prognosis to M1a [28]. So, there could have been the possibility to have grouped intrathoracic and single extrathoracic metastasis in the same M1a category, but this thought was discarded because the TNM classification is pure anatomy and the intrathoracic and extrathoracic metastases represent different anatomic ways of tumour spread that are better kept separated for a more detailed anatomic description.

In any case, the last word on the M component of the TNM classification has not been said, yet. Shortly after the publication of the $\mathrm{M}$ article [28], a group from Portugal analysed the survival of their own patients with metastatic non-small cell lung cancer and revealed two important findings: with their own data, they could validate the three M1 subcategories of the 8th edition; and that having one or two extrathoracic metastases had the same prognosis [29]. No doubt, more research is needed on the M component regarding the prognostic impact of the different metastatic sites, the volume of the lesions and their number, especially in the light of the recent interest raised by the oligometastatic state, defined as the presence of a maximum of 5 metastases in three organs [30].

\section{WHAT CAN BE EXPECTED FROM THE 9TH EDITION}

\section{8th edition stage grouping}

The stage groupings of the 8th edition [31] were developed with a sound methodology [32] and were externally validated with the SEER database [33]. Table 6 shows the 5 -year survival rates of clinical and pathologic stages of the 7th and the 8th editions TNM and their corresponding R2 values [31]. In both editions, prognosis worsens as tumour stage progresses in the clinical and pathologic staging settings, but in the 8th edition there are more stages, reflecting the impact of tumour size in the revision of the T descriptors. In the 8th edition, the R2, an estimate of the percentage variance explained by the stages, is greater both in the clinical and pathologic staging than that of the 7th edition, meaning that there has been some gain in the capacity to prognosticate based on stage groupings. However, there is a big part of prognosis that remains unexplained by the classification of anatomic extent, and the international thoracic oncology community is hoping to have a better instrument to assess prognosis in a more individualized way than the TNM classification and stage grouping. 
Table 6. Five-year survival rates of the 7th and the 8th editions stage groupings.

\begin{tabular}{cccccc}
\hline & $7^{\text {th }}$ edition & & \multicolumn{3}{c}{$\mathbf{8}^{\text {th }}$ edition } \\
\hline Stage/ $\mathbf{R}^{2}$ & Clinical & Pathologic & Stage/ $^{2}$ & Clinical & Pathologic \\
\hline IA & $82 \%$ & $83 \%$ & IA & $92 \%$ & $90 \%$ \\
IB & $66 \%$ & $71 \%$ & IA2 & $83 \%$ & $85 \%$ \\
IIA & $52 \%$ & $57 \%$ & IA3 & $77 \%$ & $80 \%$ \\
IIB & $47 \%$ & $49 \%$ & IB & $66 \%$ & $73 \%$ \\
IIIA & $36 \%$ & $36 \%$ & IIA & $60 \%$ & $65 \%$ \\
IIIB & $19 \%$ & $23 \%$ & IIB & $53 \%$ & $56 \%$ \\
IV & $6 \%$ & & IIIA & $36 \%$ & $41 \%$ \\
& & & IIIB & $26 \%$ & $24 \%$ \\
& & & IIIC & $13 \%$ & $12 \%$ \\
& & & IVA & $10 \%$ & \\
R $^{2}$ & 65.5 & 45.7 & IVB & $0 \%$ & \\
& & & & 68.3 & 46.9 \\
\hline
\end{tabular}

\section{A purposeful change of name}

At the IASLC Board of Directors Meeting of February 2013, upon request from the leadership of the IASLC Staging Committee, the name of the committee was changed from Staging Committee to Staging and Prognostic Factors Committee (SPFC). The change in the name implied that the activities of the SPFC were not going to be limited to the exclusive study and revision of the classification of anatomic extent of thoracic malignancies, but would be expanded to the study of other non-anatomic prognostic factors, following the trend initiated by the UICC and AJCC [34]. There are many factors that influence prognosis in lung cancer patients. These have been classified as tumour-related, patientrelated and environment-related and need to be thoughtfully combined to refine prognosis [35].

\section{Prognostic groups}

The combination of tumour-, patient- and environmentrelated prognostic factors to build clinically relevant prognostic groups that contribute to a more precise prognosis [36] needs a sound and strict methodology [37]. Exploratory analyses to assess the prognostic impact of the combination of anatomic extent and patient-related factors were done with the database of the 7th edition. The combination of staging, age, sex and performance status resulted in four prognostic groups with significantly different prognosis both in patients with small cell lung cancer and non-small cell lung cancer [38, 39]. However, nowadays, we cannot think of building prognostic groups without the inclusion of molecular data that constitute part of tumour profile [36]. Therefore, the IASLC SPFC has incorporated three new subcommittees to manage the complex development of prognostic groups. These are the Prognostic Factors Subcommittee, the Methodology Subcommittee and the Molecular Subcommittee. Molecular factors, such as genetic biomarkers, copy number alteration biomarkers and protein alteration, have been incorporated into the list of items to be collected in the dataset designed to develop the 9th edition TNM and prognostic groups. However, molecular factors are not the only prognostic factors and they do not have to be studied in isolation without considering the clinical and environmental context.

The objective of the IASLC SPFC for the 9th edition TNM of lung cancer is to further revise the classification of anatomic extent of the tumour, provided that the analyses of the new database offer solid enough results that can be used to recommend changes in the 8th edition, and to combine TNM, clinical prognostic factors, tumour profile (including molecular factors) and environmental factors (such as geographic origin of the patient) into prognostic groups with the intention to improve the assessment of prognosis provided by the TNM classification. This is no easy task and the IASLC SPFC relies on the generosity of the thoracic oncologic community around the world to collect the largest possible database to achieve this ambitious objective.

Participating in the IASLC Staging Project is both personally and professionally rewarding no matter the type of participation one is involved in: member of the committee, member of the advisory boards or data contributor. International contribution is essential to make further progress. If the reader of this article is willing to contribute cases, simply send a short message expressing your interest to participate to webhelpIASLC@crab.org with IASLC Lung Cancer Staging Project in the subject line and you will receive all the necessary information to start your activity in one of the most intellectually challenging professional activities in thoracic oncology.

\section{CONCLUSION}

The TNM classification of lung cancer has experienced revisions and refinements over the past five decades, and its eight editions have improved our understanding of anatomic tumour extent regarding prognosis, therapy and research. The innovations of the two latest editions, namely the 7th and the 8th, were based on large international databases that have allowed solidly based revisions. Yet, prognosis is not only based on the anatomic extent of lung cancer, but on tumour-, patient- and environment-related prognostic factors that are not considered in the TNM classification. The challenge for the 9th edition is to combine anatomic and non-anatomic prognostic factors into prognostic groups that will allow the clinician to better assess the prognosis of the disease more selectively for the individual patients. This endeavour needs international commitment and participation to create a large and complete database to achieve this ambitious objective. 


\section{REFERENCES}

[1] Brierley JD, Gospodarowicz MK, Wittekind Ch, eds. UICC TNM Classification of Malignant Tumours. Eighth edition. Oxford: Wiley Blackwell; 2017.

[2] Amin MB, ed. AJCC Cancer Staging Manual. Eighth edition. Springer; 2017.

[3] Rami-Porta R, ed. IASLC Staging Manual in Thoracic Oncology. North Fort Myers, FL: Editorial Rx Press; 2016.

[4] Giroux DJ, Van Schil P, Asamura $\mathrm{H}$ et al. The IASLC Lung Cancer Staging Project: a renewed call to participation. J Thorac Oncol 2018; 13: 801-809. DOI:10.1016/j.jtho.2018.02.012

[5] Goldstraw P. The history of TNM staging in lung cancer. In: Rami-Porta R (ed). IASLC Staging Manual in Thoracic Oncology, 2nd edition; North Forth Myers Editorial Rx Press; 2016; p: 67-78.

[6] Goldstraw P, Crowley JJ. The International Association for the Study of Lung Cancer International Staging Project on Lung Cancer. J Thorac Oncol 2006; 1: 281-286.

[7] Rami-Porta R, Bolejack V, Giroux DJ et al. The IASLC Lung Cancer Staging Project: the new database to inform the eighth edition of the TNM classification of lung cancer. J Thorac Oncol 2014; 9: 1618-1624. DOI:10.1097/JTO.0000000000000334

[8] Rami-Porta R, Ball D, Crowley J et al. The IASLC lung cancer staging project: proposals for the revision of the $\mathrm{T}$ descriptors in the forthcoming (seventh) edition of the TNM classification for lung cancer. J Thorac Oncol 2007; 2: 593-602. DOI:10.1097/JTO.0b013e31807a2f81

[9] Rami-Porta R, Bolejack V, Crowley J et al. The IASLC Lung Cancer Staging Project: proposals for the revisions of the T descriptors in the forthcoming 8th edition of the TNM classification for lung cancer. J Thorac Oncol 2015; 10 : 990-1003. DOI:10.1097/JTO.0000000000000559

[10] Travis WD, Brambilla E, Noguchi M, et al. The New IASLC/ATS/ERS international multidisciplinary classification of lung adenocarcinoma. J Thorac Oncol 2011;6:244-285. DOI:10.1097/JTO.0b013e318206a221

[11] Travis WD, Brambilla E, Burke AP, Marx A, Nicholson AG. WHO Classification of Tumours of the Lung, Pleura, Thymus and Heart. Lyon: International Agency for Research on Cancer; 2015.

[12] Travis WD, Asamura H, Bankier A et al. The IASLC Lung Cancer Staging Project: proposals for coding T categories for subsolid nodules and assessment of tumor size in partsolid tumors in the forthcoming eighth edition of the TNM classification of lung cancer. J Thorac Oncol 2016; 11: 1204-1223. DOI:10.1016/j.jtho.2016.03.025

[13] Travis WD, Brambilla E, Rami-Porta R et al. Visceral pleural invasion: pathologic criteria and use of elastic stains. Proposal for the 7 th edition of the TNM classification for lung cancer. J Thorac Oncol 2008; 3: 1384-1390. DOI:10.1097/JTO.0b013e31818e0d9f

[14] Taube JM, Askin FB, Brock MV, Westra W. Impact of elastic staining on the staging of peripheral lung cancers. Am J Surg Pathol 2007; 31: 953-956. DOI:10.1097/PAS.0b013e31802ca413

[15] Detterbeck FC, Nicholson AG, Franklin WA et al. The IASLC Lung Cancer Staging Project: summary of proposals for revisions of the classification of lung cancers with multiple pulmonary sites of involvement in the forthcoming eighth edition of the TNM classification. J Thorac Oncol 2016; 11: 539-650. DOI:10.1016/j.jtho.2016.01.024

[16] Detterbeck FC, Franklin WA, Nicholson AG et al. The IASLC Lung Cancer Staging Project: background data and proposed criteria to distinguish separate primary lung cancers from metastatic foci in patients with two lung tumors in the forthcoming eighth edition of the TNM classification for lung cancer. J Thorac Oncol 2016; 11: 651-665. DOI:10.1016/j.jtho.2016.01.025

[17] Detterbeck FC, Bolejack V, Arenberg DA et al. The IASLC Lung Cancer Staging Project: background data and proposals for the classification of lung cancer with separate tumor nodules in the forthcoming eighth edition of the
TNM classification for lung cancer. J Thorac Oncol 2016; 11: 681-692. DOI:10.1016/j.jtho.2015.12.114

[18] Detterbeck FC, Marom EM, Arenberg DA et al. The IASLC Lung Cancer Staging Project: background data and proposals for the application of TNM staging rules to lung cancer presenting as multiple nodules with ground glass or lepidic features or a pneumonic-type of involvement in the forthcoming eighth edition of the TNM classification. J Thorac Oncol 2016; 11: 666-680. DOI:10.1016/j.jtho.2015.12.113

[19] Travis WD, Giroux DJ, Chansky K, et al. The IASLC Lung Cancer Project: proposals for the inclusion of bronchopulmonary carcinoid tumors in the forthcoming (seventh) edition of the TNM classification for lung cancer. J Thorac Oncol 2008; 3: 1213-1223. DOI:10.1097/JTO.0b013e31818b06e3

[20] Shepherd FA, Crowley J, Van Houtte P, et al. The International Association for the Study of Lung Cancer Lung Cancer Staging Project: proposals regarding the clinical staging of small cell lung cancer in the forthcoming (seventh) edition of the tumor, node, metastasis classification for lung cancer. J Thorac Oncol 2007; 2: 1067-1077. DOI:10.1097/JTO.0b013e31815bdc0d

[21] Vallières E, Shepherd FA, Crowley J, et al. The IASLC Lung Cancer Staging Project. Proposals regarding the relevance of the TNM in the pathologic staging of small cell lung cancer in the forthcoming (seventh) edition of the TNM classification for lung cancer. J Thorac Oncol 2009; 4: 1049-1059. DOI:10.1097/JTO.0b013e3181b27799

[22] Nicholson AG, Chansky K, Crowley J et al. The International Association for the Study of Lung Cancer Lung Cancer Staging Project: proposals for the revision of the clinical and pathologic staging of small cell lung cancer in the forthcoming eighth edition of the TNM classification for lung cancer. J Thorac Oncol 2016; 11: 300-311. DOI:10.1016/j.jtho.2015.10.008

[23] Rami-Porta R. Quantification of regional lymph node involvement in lung cancer. Thorax 2011; 66: 271-272. DOI:10.1136/thx.2010.155010

[24] Rusch VW, Crowley J, Giroux DJ, et al. The IASLC Lung Cancer Staging Project: proposals for the revision of the N descriptors in the forthcoming seventh edition of the TNM classifications for lung cancer. J Thorac Oncol 2007; 2: 603-612. DOI:10.1097/JTO.0b013e31807ec803

[25] Rusch VW, Asamura H, Watanabe H, Giroux DJ, RamiPorta R, Goldstraw P. The IASLC Lung Cancer Staging Project. A proposal for a new international lymph node map in the forthcoming seventh edition of the TNM classification for lung cancer. J Thorac Oncol 2009; 4: 568-577. DOI:10.1097/JTO.0b013e3181a0d82e

[26] Asamura H, Chansky K, Crowley J et al. The IASLC Lung Cancer Staging Project: proposals for the revisions of the $\mathrm{N}$ descriptors in the forthcoming 8th edition of the TNM classification for lung cancer. J Thorac Oncol 2015; 10: 1675-1684. DOI:10.1097/JTO.0000000000000678

[27] Postmus PE, Brambilla E, Chansky K, et al. The IASLC Lung Cancer Staging Project: proposals for revision of the $\mathrm{M}$ descriptors in the forthcoming (seventh) edition of the TNM classification of lung cancer. J Thorac Oncol 2007; 2: 686-693. DOI:10.1097/JTO.0b013e31811f4703

[28] Eberhardt WE, Mitchell A, Crowley J et al. The IASLC Lung Cancer Staging Project: proposals for the revisions of the $\mathrm{M}$ descriptors in the forthcoming 8th edition of the TNM classification for lung cancer. J Thorac Oncol 2015; 10: 1515-1522. DOI:10.1097/JTO.0000000000000673

[29] Dias M, Antunes A, Campainha S, Conde S, Barroso A. Prognostic impact of $M$ descriptors of the 8th edition of TNM classification of lung cancer. J Thorac Dis 2017; 9: 685-691. DOI:10.21037/jtd.2017.03.106

[30] Dingemans A, Hendriks L, Berghmans T et al. Searching for a definition of synchronous oligometastatic (SOMD)NSCLC: a consensus from thoracic oncology experts. J Thorac Oncol 2018; 13 (10S): S446. 
[31] Goldstraw P, Chansky K, Crowley J et al. The IASLC Lung Cancer Staging Project: proposals for the revision of the stage grouping in the forthcoming (8th) edition of the TNM classification of lung cancer. J Thorac Oncol 2016; 11: 3951. DOI:10.1016/j.jtho.2015.09.009

[32] Detterbeck FC, Chansky K, Groome P et al. The IASLC Lung Cancer Staging Project: methodology and validation used in the development of proposals for revision of the stage classification of NSCLC in the forthcoming (eighth) edition of the TNM classification of lung cancer. J Thorac Oncol 2016; 11: 1433-1446.

DOI:10.1016/j.jtho.2016.06.028

[33] Chansky K, Detterbeck FC, Nicholson AG et al. The IASLC Lung Cancer Staging Project: external validation of the revision of the TNM stage groupings in the eighth edition of the TNM classification of lung cancer. J Thorac Oncol 2017; 12: 1109-1121. DOI:10.1016/j.jtho.2017.04.011

[34] Greene FL, Sobin LH. A worldwide approach to the TNM staging system: collaborstive efforts of the AJCC and UICC. J Surg Oncol 2009; 99: 269-272.

DOI: $10.1002 /$ jso.21237
[35] Greene FL, Sobin LH. The staging of cancer: a retrospective and prospective appraisal. CA Cancer J Clin 2008;58:180-190. DOI: 10.3322/CA.2008.0001

[36] Rami-Porta R, Asamura H, Brierly J, Goldstraw P. Staging, tumor profile, and prognotic groups in lung cáncer or the new Tower of Babel. J Thorac Oncol 2016; 11: 12011203. DOI: 10.1016/j.jtho.2016.04.019

[37] Detterbeck F. Developing a prognostic prediction model for lung cancer. In Rami-Porta R (ed). IASLC Staging Manual in Thoracic Oncology. North Fort Myers, FL: Editorial Rx Press; 2016; p: 237-258.

[38] Sculier JP, Chansky K, Crowley JJ, van Meerbeeck JV, Goldstraw P. The impact of additional prognostic factors on survival and their relationship with the anatomical extent of disease expressed by the 6th edition of the TNM classification of malignant tumors and the proposals for the 7th edition. J Thorac Oncol 2008; 3: 457-466. DOI: 10.1097/JTO.0b013e31816de2b8

[39] Chansky K, Sculier JP, Crowley JJ, Giroux D, van Meerbeeck J, Goldstraw P. The International Association for the Study of Lung Cancer staging project. Prognostic factors and pathologic TNM stage in surgically managed non-small cell lung cancer. J Thorac Oncol 2009; 4: 792801. DOI: 10.1097/JTO.0b013e3181a7716e 